\title{
COMPARABILITY OF NETWORK KNOWLEDGE OF THE SIGNALS AND INFORMATION BRANCH OFFICER, WARRANT OFFICER AND NCO CANDIDATES WITH SCOPE ON CISCO NETWORKING ACADEMY TRAINING-NETACAD PROGRAM
}

\author{
A HÍRADÓ ÉS INFORMATIKAI HONVÉD TISZT, ALTISZT ÉS \\ ZÁSZLÓSJELÖLTEK HÁLÓZATI ISMERETEKKEL KAPCSOLATOS TUDÁSA \\ EGYMÁSNAK VALÓ MEGFELELTETHETŐSÉGE A CISCO HÁLÓZATI \\ AKADÉMIAI KÉPZÉS-NETACAD PROGRAM TÜKRÉBEN
}

\author{
JOBBÁGY Szabolcs \\ (ORCID: 0000-0002-2104-4665) \\ jobbagy.szabolcs@uni-nke.hu
}

\begin{abstract}
In my PhD thesis I researched the possibility and necessity of revising the new type two years long scholar education of NCO basic education, signals and military information system operator branch, and the complementary warrant officer, signals and information branch half years training type, competency based modular professional education at HDF NCO Academy, with scope on CISCO Networking Academy TrainingNetAcad Program. In the recent paper I analyse within a comparative study, whether the knowledge of the succeeding officer, warrant officer and NCO personnel can be compared to each other after graduation.
\end{abstract}

Keywords: NetAcad Program, IT Essentials PC Hardware \& Software, CCNA Routing \& Switching.

\begin{abstract}
Absztrakt
Doktori (PhD) értekezésemben a Magyar Honvédség Altiszti Akadémia (MH AA) honvéd altiszt alap szakképesítés híradó, és katonai informatikai-rendszer üzemeltető ágazatának és szakmairányainak új típusú, kétéves, nappali, iskolarendszerü, illetve a honvéd zászlós ráépülő szakképesítés híradó és informatikai ágazatának belső, féléves, tanfolyami rendszerü, kompetenciaalapú, moduláris jellegü szakképzési rendszere átalakításának lehetőségét és annak szükségességét vizsgáltam a CISCO Hálózati Akadémiai Képzés - NetAcad Program tükrében. Jelen közleményemben egy összehasonlitó elemzés formájában azt vizsgálom meg, hogy a végzést követően a honvéd tiszt, altiszt és zászlósjelöltek hálózati ismeretekkel kapcsolatos tudása mennyire feleltethető meg egymásnak.
\end{abstract}

Kulcsszavak: NetAcad Program, IT Essentials PC Hardware \& Software, CCNA Routing \& Switching. 


\section{INTRODUCTION}

In my $\mathrm{PhD}$ thesis bearing the title „On developing the digital professional knowledge of the signal and information NCO and warrant officer operating personnel", I surveyed among other things also the possibility of fitting the knowledge material of different courses and their modules reachable on each levels of CISCO Networking Academy Training-NetAcad Program into the signal and information education portfolio of HDF NCO Academy, and if possible, through which means. My motivation to this was that countless scientific work have already been done on the effects of digitalisation on stationary (fixed) and field (mobile) information systems providing the fundament of HDF's infocommunication network, on the organisation of information transmission, on organisational and operational order, in general about the shift from analogous to digital systems. In 1994 András László analysed the evolving and developing of digital broadcasting, and its appearance and possible utilisation within HDF's information network in his PhD thesis. [1] In 2001 Zoltán Rajnai aimed in his work at analysing basic field (mobile) information network, and the possibilities of its digitalisation with the communication systems of each NATO members in scope. [2] In 2003 Károly Fekete searched the possibilities of further development in the stationary (fixed) communication system of HDF. [3] In 2007 Sándor Szöllősi discussed the development trends and technical utilisation of converging networks within HDF infocommunication system in his PhD thesis. [4] In 2015 András Tóth searched the possibilities of realising network enabled capability features in the communication network of HDF. [5] However most of these analyse the effects of digital society and digitalisation itself only from one aspect, that of technology and service. As a result, several proposals are given regarding network infrastructure, devices, transport capabilities, network provided services, interoperability and compatibility, also in regard of possible connection with other nations' networks. At the same time not much is said about the operating personnel, the signals and IT workforce. Their digital knowledge has to be developed as well. They have to be provided with the capability of digital literacy. Thus, in my hypothesis I assumed, that, ,the Hungarian Defence Forces (HDF) hasn't become fully able to adopt and convert the knowledge appropriate to the task and function system utilised in the leading NATO and European militaries into the professional NCO and warrant officer training. As a result, the signal and information education system at HDF NCO Academy does not meet the requirements of the age of digitalisation properly either. The professional digital knowledge reachable within the training isn't meeting the technology and services utilised in the infocommunication network and digital systems of HDF fully. Thus, the revising and reshaping of it is necessary. In the frames of development of the human resource's digital knowledge the operating personnel can be outfitted with up-to-date professional knowledge and features, through which we can educate an expert for the organisation, at the same time possessing a knowledge valuable in the IT segment of the civilian sphere, being competitive and convertible. As a result, we can also support their employment in the connecting fields of public service in case of leaving the organisation because of a changed career model, and their success in the market of civilian IT sphere as well." [6; pp. 9-10.]

That I did the above research regarding the named educational system had several reasons. One is that NetAcad Program CCNA Routing \& Switching (CCNA R\&S) knowledge material gives a fundamental part of education for National University of Public Service, Faculty of Military Science and Officer Training, Institute of Maintenance, Signals Department (NUPS FMSOT IM SD) at BSc level, signals specialisation, transmission and information security module in form of network knowledge connected courses. [6; pp. 85-86.][6; pp. 92-94.][6; pp. 114-128.][7] Otherwise, at the beginning of my research I also optionally planned to analyse the possibility of integration of either the professional level Routing \& Switching(CCNP R\&S) [6; pp. 85-86.][6; pp. 94-95.][8] or any similar level course on other fields to NUPS FMSOT 
IM SD MSc level portfolio. But thinking further and consulting with my supervisor after preanalysing the named training, I got to the assumption that because of its narrow timeframe there would be no possibility to integrate that knowledge material. At the same time, the training type education at NUPS FMSOT IM SD, also being present in the yearly education plan of the Personnel Directorate and Infocommunication and Information Security Directorate since years could be a solution to this gap. This is an opportunity given and reachable for everyone meeting the expectations, without any regard to assignment or rank. The education is based on the CCNA R\&S information network builder and operator training within NetAcad Program.

In this present paper I'm searching the answer to the following question. In case of realising the recommendations of my $\mathrm{PhD}$ thesis in the practice on the revision and restructuring of the HDF NCO Academy's NCO basic professional certification, signal branch and warrant officer comprehensive professional certification, signal and information branch professional education system, at what volume could the gained knowledge of these be compared to the knowledge of officer candidates studying on the two courses of NUPS FMSOT IM SD specialisation mentioned above? At what level would the knowledge base of each personnel category meet each other, would the NCO-s and warrant officers be ready to meet the expectations of the officers in accordance to efficient, successful and cooperative fulfilling of their tasks given?

\section{COMPARISON OF THE EDUCATION PORTFOLIO OF RELEVANT BRANCHES REGARDING NETWORK KNOWLEDGE AT NUPS FMSOT IM SD BSC LEVEL, AND NCO ACADEMY PROFESSIONAL TRAINING}

NetAcad Program is present in the education portfolio of NUPS FMSOT IM SD since 2010 as a definitive field of education regarding the training of officer candidates. An official CISCO Academy works since 2009, maintained by the Signal Department. The knowledge material of CCNA R\&S at Associate level is fundamental part of the education since 2012 in form of courses, recently of the education of third and fourth year cadets at Military Operator basic education, Signals specialisation, transmission and information security module, at BSc level. This was also true to the ancestor Military and security technology education, and its relevant specialisations before the Academy Evolution procedure in 2012. From 2011 IT networkconnected knowledge was integrated within the frames of CISCO Discovery course and its modules. The courses of the four semesters containing the knowledge material in a comprehensive way are as follows:

- Signals specialisation, Transmission module

- HHIRB01 Basics of networks

○ HHIRB06 Military networks I

○ HHIRB11 Military networks II

o HHIRB16 Military networks III

- Signals specialisation, Information security module

○ HHIRB01 Basics of networks

○ HHIRB20 KIB network knowledge I

○ HHIRB24 KIB network knowledge II

○ HHIRB30 KIB network knowledge III

The CISCO Certified Network Associate level R\&S education comprises of four different modules as follows: [6; pp. 114-128][9][10]

- Introduction to Networks (ITN)

- Routing and Switching Essentials (RSE)

- Scaling Networks (ScaN)

- Connecting Networks (CN) 
According to these the comparability of knowledge material of each module and courses are held in the table below.

\begin{tabular}{|c|c|c|c|c|}
\hline & \multicolumn{4}{|c|}{$\begin{array}{l}\text { CISCO Networking Academy Training-NetAcad Program } \\
\text { CCNA R\&S modules }\end{array}$} \\
\hline & ITN & RSE & ScaN & $\mathbf{C N}$ \\
\hline \multicolumn{5}{|c|}{ Courses } \\
\hline \multicolumn{5}{|c|}{ Signals specialisation, Transmission module } \\
\hline HHIRB01 & $\mathbf{X}$ & & & \\
\hline HHIRB20 & & $\mathbf{X}$ & & \\
\hline HHIRB11 & & & $\mathbf{X}$ & \\
\hline HHIRB16 & & & & $\mathbf{X}$ \\
\hline \multicolumn{5}{|c|}{ Signals specialisation, Information security module } \\
\hline HHIRB01 & $\mathbf{X}$ & & & \\
\hline HHIRB20 & & $\mathbf{X}$ & & \\
\hline HHIRB24 & & & $\mathbf{X}$ & \\
\hline HHIRB30 & & & & $\mathbf{X}$ \\
\hline
\end{tabular}

1. table Comparison of NetAcad Program CCNA R\&S course modules and the knowledge material of the courses regarding network knowledge at signals specialisation (author's own)

According to my proposal in the PhD thesis, I expect the knowledge material of IT Essentials PC Hardware and Software (ITE) course to be ready to introduce to NQR54 NCO basic certification, signals branch, radio station operator specialisation as „Information technology basics (PC hardware and software)" course. [6; (App. No.24.) pp. 73-128.] In case of NQR54 certification, transmission- and switch technology operator specialisation I regard ITE, ITN and RSA courses of CCNA R\&S training suitable to introduce, in form of „Information technology basics (PC hardware and software)" course. [6; (No.24. app.) pp. 73-128.] for ITE, „Network knowledge” [6; (App. No.25.) pp. 314-318.] for ITN and „Networks I.” [6; (App. No. 26.) pp. 319-322.] for RSE course.

To NQR55 warrant officer comprehensive certification, signals and information branch I view the knowledge material of ITE course to be possible and necessary to obtain in form of a new „Information technology basics (PC hardware and software)” course. [6; (App. No.27.) pp. 323-327.]

As a summarisation to the above, the further table holds the courses and modules available in network academy education, which is or can be integrated to the officer, warrant officer and NCO education. 


\begin{tabular}{|c|c|c|c|c|c|}
\hline & \multicolumn{5}{|c|}{$\begin{array}{c}\text { CISCO Networking Academy Training-NetAcad } \\
\text { Program education levels and modules }\end{array}$} \\
\hline & ITE & $\begin{array}{c}\text { CCNA } \\
\text { R\&S } \\
\text { ITN }\end{array}$ & $\begin{array}{c}\text { CCNA } \\
\text { R\&S } \\
\text { RSE }\end{array}$ & $\begin{array}{c}\text { CCNA } \\
\text { R\&S } \\
\text { ScaN }\end{array}$ & $\begin{array}{c}\text { CCNA } \\
\text { R\&S } \\
\text { CN }\end{array}$ \\
\hline \multicolumn{6}{|c|}{ Officer Training } \\
\hline $\begin{array}{l}\text { NUPS FMSOT Military } \\
\text { Operator basic } \\
\text { certification, Signals } \\
\text { specialisation, } \\
\text { Transmission module }\end{array}$ & - & $\mathbf{X}$ & $\mathbf{X}$ & $\mathbf{X}$ & $\mathbf{X}$ \\
\hline $\begin{array}{l}\text { NUPS FMSOT Military } \\
\text { Operator basic } \\
\text { certification, Signals } \\
\text { specialisation, Information } \\
\text { security module }\end{array}$ & - & $\mathbf{X}$ & $\mathbf{X}$ & $\mathbf{X}$ & $\mathbf{X}$ \\
\hline \multicolumn{6}{|c|}{ NCO and Warrant Officer Training } \\
\hline $\begin{array}{l}\text { HDF NCO Academy } \\
\text { NQR54 NCO basic } \\
\text { certification, Signals } \\
\text { branch, Radio-station } \\
\text { operator specialisation }\end{array}$ & $\mathbf{X}$ & - & - & - & - \\
\hline $\begin{array}{l}\text { HDF NCO Academy } \\
\text { NQR54 NCO basic } \\
\text { certification, Signals } \\
\text { branch, Transmission and } \\
\text { switch technology operator } \\
\text { specialisation }\end{array}$ & $\mathbf{X}$ & $\mathbf{X}$ & $\mathbf{X}$ & - & - \\
\hline $\begin{array}{l}\text { HDF NCO Academy } \\
\text { NQR55 warrant officer } \\
\text { comprehensive } \\
\text { certification, Signals and } \\
\text { information specialisation }\end{array}$ & $\mathbf{X}$ & - & - & - & - \\
\hline
\end{tabular}

2. table Courses and modules available in NetAcad Program, which are or can be integrated to the officer, warrant officer and NCO education (author's own)

According to the above, the question can be answered like that. The officer candidates at NUPS FMSOT Military operator basic certification, Signals specialisation, BSc level gain all the theoretical and practical knowledge, and even more regarding network systems, that is planned to be integrated to the Signals specialised education at HDF NCO Academy according to my proposals, on both specialisations. Thus the newly commissioned officers hold all the professional knowledge, digital competency and literacy, and even at higher level, than the NCO-s and warrant officers gaining certification. This means that all the officers, warrant officers and NCO-s bear all the necessary theoretical and practical knowledge, professional literacy, knowledge of technology, devices and uniform terminology during the fulfilling of their professional assignment that enables successful and cooperative achievement of their tasks and orders.

Regarding possible professional difficulties among the different personnel categories stemming basically from the fact that given professional might not hold the necessary 
knowledge on their field because of lesser volume of education - can be tackled by complementary solution. For this, CCNA R\&S Information network builder and operator training maintained by the Signals Department since 2010, as mentioned earlier, provides an excellent solution, which is meant to give the knowledge material of the above discussed courses and modules to the partaking officers, warrant officers and NCO-s. This is also the reason for my further proposal on complementing the education portfolio of CA with IT Essentials PC Hardware and Software course, to which I also processed the necessary education program. [6; (App. No. 28.) pp. 328-337.] Beyond these, the newly founded CA on the fundaments of HDF NCO Academy in cooperation of the already existing CA can function as an interim solution to the professional training and broadening of the knowledge of the personnel. [6; pp. 166-169.]

\section{CONCLUSIONS}

Summarising the above, it can be clearly stated, that the officers, warrant officers and NCO-s gain the theoretical and practical knowledge material of the named courses by processing the same online education material within the frames of NetAcad Program with the cooperation of the given CA. The education background to this is provided by the very same e-learning surface, and broad spectrum engineer type technology program, involving comprehensive education levels, courses and evaluation levels. As a result, during the further professional career all the matching points, similar or equivalent knowledge, up-to-date professional literacy, digital competency will be given, that enables the NCO-s and warrant officers to meet the professional expectations of the officers through their knowledge on technology, devices, converged services and uniform terminology.

\section{BIBLIOGRAPHY}

[1] LÁSZLÓ András: A digitális hírközlés kialakulása és fejlődése, megjelenése és alkalmazási lehetőségei a Magyar Honvédség hírrendszerében. - Bp., PhD thesis, 1994.

[2] RAJNAI Zoltán: A tábori alaphírhálózat vizsgálata és digitalizálásának lehetőségei egyes NATO tagországok kommunikációs rendszereinek tükrében. - Bp., PhD thesis, 2001.

[3] FEKETE Károly: A Magyar Honvédség állandó telepítésü kommunikációs rendszere továbbfejlesztésének technikai lehetőségei. - Bp., PhD thesis, 2003.

[4] SZÖLLŐSI Sándor: Konvergáló hálózatok fejlődési trendjei, a technikai alkalmazhatóság kérdései a Magyar Honvédség infokommunikációs rendszerében. - Bp., PhD thesis, 2007.

[5] TÓTH András: A hálózat nyújtotta képesség megvalósításának lehetőségei a Magyar Honvédség kommunikációs rendszerében. - Bp., PhD thesis, 2015.

[6] JOBBÁGY Szabolcs: A honvéd altiszt és zászlós híradó és informatikai üzemeltető állomány digitális szakmai ismereteinek fejlesztése; PhD thesis; Budapest 2018

[7] CISCO Associate Certifications; http://www.cisco.com/c/en/us/training-events/trainingauthiridations/certifications/associate.html (Downloaded: 12.08.2018.) (Translated by the

[8] CISCO Professional Certifications; http://www.cisco.com/c/en/us/trainingevents/training-certifications/certifications/professional.html (Downloaded: 12.08.2018.) (Translated by the author) 
[9] CCNA Routing and Switching tananyag; http://netacad.hu/ccna-rs (Downloaded: 12.08.2018.)

[10] CCNA Routing \& Switching online tananyag; www.netacad.com (Downloaded: 12.08.2018.) 